Cornell Law Library

Scholarship@Cornell Law: A Digital Repository

Cornell Law Faculty Publications

Faculty Scholarship

$12-1978$

\title{
Professor Fuller's Jurisprudence and America's Dominant Philosophy of Law
}

Robert S. Summers

Cornell Law School, rss25@cornell.edu

Follow this and additional works at: http://scholarship.law.cornell.edu/facpub

Part of the Jurisprudence Commons, and the Legal History, Theory and Process Commons

\section{Recommended Citation}

Summers, Robert S., "Professor Fuller's Jurisprudence and America's Dominant Philosophy of Law" (1978). Cornell Law Faculty Publications. Paper 1351.

http://scholarship.law.cornell.edu/facpub/1351

This Article is brought to you for free and open access by the Faculty Scholarship at Scholarship@Cornell Law: A Digital Repository. It has been accepted for inclusion in Cornell Law Faculty Publications by an authorized administrator of Scholarship@Cornell Law: A Digital Repository. For more information, please contact jmp8@cornell.edu. 


\title{
PROFESSOR FULLER'S JURISPRUDENCE AND AMERICA'S DOMINANT PHILOSOPHY OF LAW
}

\author{
Robert S. Summers *
}

The late Lon $L$. Fuller played an infuential role in the development of American jurisprudence, but his views have not always prevailed. In this tribute to the memory of Professor Fuller, Professor Summers outlines the major tenets of what he perceives to be our dominant philosophy of law- "pragmatic instrumentalism"-by way of contrasting that philosophy with the views of Professor Fuller. Professor Summers concludes that these two philosophies differ in many important respects and that our dominant philosophy of law should accommodate, and may indeed already be in the process of accommodating, the thought of Professor Fuller.

$\mathrm{D}$ URING Lon L. Fuller's lifetime, philosophical pragmatism, sociological jurisprudence, and the saner tenets of legal realism coalesced to form our dominant philosophy of law - a body of views that may aptly be called "pragmatic instrumentalism." 1 Although Professor Fuller emerged as one of America's foremost jurists, he was not an adherent of this philosophy. ${ }^{2}$ The relation between his jurisprudence and pragmatic instrumentalism has not been previously explored. The subject is appropriate for a tribute to his memory. His writings, more than those of any other theorist of his day, provide pragmatic instrumentalism with needed correctives. If that philosophy eventually accommodates Professor Fuller's views, its right to rule will be more secure (and its name will no longer be apt).

As with most movements in social thought, it is not possible to trace the origins of pragmatic instrumentalism to a single thinker. ${ }^{3}$ This philosophy is the work of a number of theorists, both "classical" and "contemporary." The former are of primary

* McRoberts Professor of Law, Cornell University.

I wish to thank Mr. Erik M. Jensen, third year student at Cornell Law School, for valuable research aid, discussion, and editorial assistance. I am also grateful to Professors Martin P. Golding, R. Kent Greenawalt, Alan Gunn, David Lyons, and Kenneth I Winston, who kindly commented on an earlier draft.

${ }^{1}$ John Dewey occasionally used this phrase. See, e.g., J. DEWEY, THE QUEST FOR CertaINTy $37^{\prime}$ (I929). His usage, however, was somewhat different from mine, and $I$ adapt the term for use here.

2 This is not to say that no "accents of American pragmatism" are discernible in his work. See Selznick, Book Review, 83 HaRv. L. Rev. I474, 3475 (I970).

${ }^{3}$ On its origins, see generally E. Patterson, Jurisprudence: Men and IDEAS OF THE LAW $465-558$ (I953). 
interest here. ${ }^{4}$ Not all wrote on law, ${ }^{5}$ but those who did include Oliver Wendell Holmes, Jr. (I84I-I935), John Chipman Gray (I839-I9I5), John Dewey (I859-I952), ${ }^{7}$ Roscoe Pound (I870I964), ${ }^{9}$ Joseph Walter Bingham (I878-1973), ${ }^{10}$ Karl N. Llewellyn (I893-I962), ${ }^{11}$ Walter Wheeler Cook (I873-I943), ${ }^{12}$ Underhill Moore (I879-I949), ${ }^{13}$ and Jerome Frank (I889I957).$^{14}$ This list is not exhaustive. ${ }^{15}$ And these thinkers did not

${ }^{4}$ As I have indicated, these include philosophical pragmatists, sociological jurists, and legal realists. I am not, of course, the first to see this general coalescence of thought. See, e.g., id. at 556 .

${ }^{5}$ Important philosophical pragmatists who did not write on law include Charles Sanders Peirce (I839-I9I4) and William James (I842-19I0). Yet there was much interchange between these thinkers and legal scholars, including Holmes. See Fisch, Justice Holmes, the Prediction Theory of Law, and Pragmatism, 39 J. PHIIOSOPHX 85 (I942).

${ }^{6}$ See, e.g., O.W. Holmes, Collected Legal Papers (1920); O.W. Holmes, The Common Law (I88I); Holmes-Laski Letrers (M. Howe ed. I953); HolmiesPoliock LetTers (M. Howe ed. I94I).

${ }^{7}$ See, e.g., J.C. Gray, The Nature and Sources of the Law (2d ed. I921).

${ }^{8}$ See, e.g., Dewey, Force and Coercion, 26 INT'x J. ExHrcs 359 (xgx6); Dewey, Force, Violence, and Law, 5 New Republic 295 (I9I6); Dewey, John Dewey, in My Phicosophy of LAW 7I (I94I); Dewey, Logical Method and Law, ro Cornelr L.Q. I7 (1924); Dewey, Nature and Reason in Law, 25 Inx'L J. Etrics 25 (I9I4).

${ }^{9}$ See, e.g., R. Pound, JURISPRUdENCE (I959).

${ }^{10}$ See, e.g., Bingham, Joseph Walter Bingham, in My PrwosopHy of LAw 5 (I94r); Bingham, Legal Philosophy and the Law, 9 ILx. L. Rev. 98 (1914); Bingham, Science and the Law, 25 GreEN BAg 162 (x913); Bingham, What is the Law? (pts. I-2), II MiCH. L. REV. I, IO9 (I9I2).

${ }^{11}$ See, e.g., K. Lleweliyn, Jurisprudence: Realism in Theory and Practice (I962) ; K. Llewellyn, The Bramble Bush (I930); K. Llewellyn, The Common Law Tradition: Deciding Appeais (ig60).

${ }^{12}$ See, e.g., Cook, Legal Logic, 3I Conum. L. Rev. 108 (193I); Cook, Scientific Method and the Law, $\mathrm{I}_{3}$ A.B.A.J. 303 (1927); Cook, The Logical and Legal Bases of the Conflict of Laws, 33 YaLE L.J. 457 (I924); Cook, The Possibilities of Social Study as a Science, in Essays on Research In the Social ScIences 27 (L. Lyon ed. I93I); Cook, The Utility of Jurisprudence in the Solution of Legal Problems, in 5 Association of the Bar of the City of New York, Lectures on Legal TopICs I923-1924, at 335 (I928); Cook, Walter Wheeler Cook, in Mx Phrosopry of LaW 49 (I94I); Cook, Williston on Contracts: Revised Edition, 33 Irx. L. REv. 497 (I939).

${ }^{13}$ See, e.g., Moore \& Hope, An Institutional Approach to the Law of Commercial Banking, 38 YALE L.J. 703 (I929); Moore \& Sussman, Legal and Institulional Methods Applied to the Debiting of Direct Discounts (pts. I-6), 40 YaLE L.J. 38I, 555, 752, 928, I055, I2I9 (r93 I); Moore, Rational Basis of Legal Institulions, 23 ColUM. L. REv. 609 (I923).

${ }^{14}$ See, e.g., A Man's Reach: The Phimosophy of Judge Jeronfe Frank (B. Kristein ed. I965); J. Frank, Courts on Trial (I949); J. Frank, IF MEN Were ANgers (I942); J. Frank, LAw AND THE Modern MIND (I930); Frank, Mr. Justice Holmes and Non-Euclidean Legal Thinking, I7 CoRnelc L.Q. 568 (1932); Frank, Modern and Ancient Legal Pragmatism-John Dewey \& Co. vs. Aristotle (pts. I-2), 25 Notre DaMe Law. 20\%, 460 (1950).

${ }^{15}$ In my view it is representative and includes several of the most prominent 
hold identical views; ${ }^{16}$ pioneers, even in the same general directions of thought, almost never do. ${ }^{17}$ Each, however, adhered to most tenets of pragmatic instrumentalism, and several to nearly all. No significant tenet is without its fervent subscribers. ${ }^{18}$

Most instrumentalists reacted against formalism, conceptualism, and narrowness in analytical jurisprudence and in substantive law. ${ }^{10}$ They conceived of law not as a formal system or as inert matter but as a goal-directed activity designed to resolve or alleviate problems of group life. So viewed, law is far more than a source of structural or conceptual issues on which jurists of the analytical school may deploy their tools. Goals for law, how law is made, the ways it works, its effects, how it changes, and its potentialities and limits are to be the primary objects of jurisprudential study. Corollary studies for the substantive law call for scientific inquiry into the actual effects of uses of law and into what might be done to improve those uses. In these inquiries, official personnel are conceived as social engineers, and their behavior (and its impact) is a central focus.

This philosophy is "instrumentalist" in that it conceives of law not as means-goal complexes but merely as means to external goals. It is "pragmatic" in several ways. It focuses on law in action and on the practical differences that law makes. It stresses the roles of legal actors and their technological "know-how." It is experimentalist. It is pragmatic, too, in its professed contextualism - its reliance on time, place, circumstance, interests, wants, and the assumed malleability of reality rather than on theories, general principles, and the "nature of things" as sources of ends and means. In the foregoing ways, then, the phrase "prag-

and influential thinkers. For discussion of others who qualify as pragmatic instrumentalists, see Llewellyn, Some Realism about Realism-Responding to Dean Pound, 44 HARv. L. REv. I222 (I93I).

${ }^{16}$ Some of them even differed on fundamental issues. For example, although Holmes and most of the others held a positivistic theory of legal validity, Dewey did not. See, e.g., Dewey, Austin's Theory of Sovereignty, 9 PoritrcaI Scr. Q. 3I (I894); Dewey, John Dewey, in My PHrlosopery of LAW 7I, 8I-82 (I94I). Also, Holmes, unlike most others, thought judges should make law only "interstitially." Southern Pac. Co. v. Jensen, 244 U.S. 205, 22 I (I9I7) (Holmes, J., dissenting).

${ }^{17}$ See, e.g., Wiener, Pragmatism, in 3 Dictronary of the History of Ideas 55I, 55I-54 (P. Wiener ed. I973).

${ }^{18}$ Jerome Frank, for example, was an extremist on some issues. But most of his more extreme views (and this is true of other instrumentalists) may be interpreted merely as overstated versions of instrumentalist tenets. See generally sources cited note I $_{4}$ supra.

${ }^{10}$ This was in itself part of a more general development in American social thought at this time. See generally M. White, Sociar Thought in America: The Revolt AgaINST Foramaitsm (I947). 
matic instrumentalism" is specially apt as a name for our dominant philosophy of law. ${ }^{20}$

In what follows I will identify specific root tenets of pragmatic instrumentalism ${ }^{21}$ and contrast them with Professor Fuller's thought. I cannot undertake to prove here that the philosophy of pragmatic instrumentalism is dominant. ${ }^{22}$ But I am by no means the first to claim as much. ${ }^{23}$ The theorists I have named and their cited works ${ }^{24}$ indicate that this philosophy was widely influential at least among legal philosophers during most of Fuller's day. ${ }^{25}$

II

Professor Fuller often wrote as if he were contrasting his views solely with "legal positivism." ${ }^{26}$ Positivism, however, exhausts itself mainly in criteria of legal validity. Pragmatic instrumentalism is positivistic only in part. It has many other planks in its platform. ${ }^{27}$ Fuller's views clash with our leading philosophy at other important points as well.

\section{A. Basic Values}

According to many instrumentalists, the most basic values realized through law are the maintenance of order and the satisfaction of as many wants or interests as possible with the least

${ }^{20}$ Although the antecedents of some of its tenets are ancient, its immediate origins are identifiable in the revolt against formalism before the turn of the century. Thus, there is a special debt to Peirce and James. The name is therefore all the more appropriate, for it indicates this historical link to the philosophical pragmatists. See generally M. WHITE, supra note I9.

${ }^{21}$ No one has heretofore sought to identify and put all these tenets together. Here I will not elaborate (articles and even books have been written on some) or attribute tenets "thinker by thinker." Neither is required for present purposes, though I do undertake both tasks in a forthcoming book. Doubters are, of course, invited to consult the sources cited notes 6-I4 supra. But when I later turn to specific instrumentalist views that Professor Fuller opposed, I will cite a representative sampling of thinkers to whom these views are attributable. See notes 28 , 33, 38-39, 54, 72 \& 83 infra.

22 But see note 27 infra.

${ }^{23}$ See, e.g., Cowan, Jurisprudence, in 8 International ENcyclopedia of the Social Scrences 332, 336 (D. Sills ed. r968).

${ }^{24}$ See notes 6-14 supra.

${ }^{25}$ I would also go beyond this and claim that most of these views have been dominant among judges, lawyers, and other legal actors, among professors at leading law schools, and even among the informed laity.

${ }^{26}$ See, e.g., L. Fuller, ANatomy of THE LAw II2-I5 (Ig68); L. Fuller, THE Law IN QUest of ITSELF (I940); L. Fuller, The Morality of LaW IO6-i8 (rev. ed. I969).

${ }^{27}$ For the contrary view that "positivism" alone (with utilitarianism thrown in) constitutes the "ruling" philosophy of law, see R. DWORKIN, TAKING RIGHTS SERIOUSLY at vii (I9Ma) Zonline -- 92 Harv. L. Rev. 436 1978-1979 
friction. ${ }^{28}$ The ideal is a liberal and pluralistic democratic order. Fuller believed in this ideal, but he rarely wrote of order without stressing the importance of good order. ${ }^{29} \mathrm{He}$ believed that wants and interests must stand the scrutiny of reason; their mere existence cannot justify legal intervention on their behalf. ${ }^{30}$

During the nineteenth and early twentieth centuries, many jurists and some officials adopted a "scientific" approach to law, and this often led them into moral skepticism. Some, too, imported concepts of "rationalization" from psychology to the neglect of justification. Such thinkers tended too readily to classify an issue as one on which reason has nothing to say (or is stalemated) and tended to make the worth of an argument turn more on its authoritative endorsements than on its intrinsic merits. Frequently they appeared to take wants and interests for granted and to turn immediately to questions of means. (All agreed that at least means could be reasoned about.)

In contrast, Fuller saw great scope for reason in both the creation and interpretation of law. Indeed, the resolution of issues by reason was perhaps his most basic value. He did not, however, hold that reason rules all or ought to rule all. "We know in advance that we cannot reach our goal of social order founded solely on reason. But we know equally well that it is impossible to set in advance a stopping place short of our goal beyond which all effort will be in vain." 31

Relatedly, Professor Fuller rejected the unqualified contextualism of the pragmatic instrumentalists. He did not think that all goals for uses of law must be determined solely in light of problems posed by specific facts of time, place, circumstances, and prevailing wants or interests. In his view, general and wideranging notions of the right and the good almost always have some bearing on the decisions to be made. Indeed he sometimes wrote as if they were rooted in the very nature of things and thus all pervasive. ${ }^{32}$

\section{B. Means and Goals}

For most adherents of pragmatic instrumentalism, law serves simply as means to external goals. ${ }^{33}$ It thus consists essentially

${ }^{28}$ See, e.g., J.C. GRAX, supra note 7 , at I2-26; 3 R. Pound, supra note 9, at 3373. Holmes even said, "I am so sceptical as to our knowledge about the goodness or badness of laws that I have no practical criticism except what the crowd wants." I HolMES-Pollock LeTTERs, supra note 6, at I63.

${ }^{29}$ See, e.g., Fuller, Positivism and Fidelity to Law - A Reply to Professor Hart, 7 I HARV. L. REv. 630 (I958).

${ }^{30}$ See, e.g., L. FUlLeR, The LAW IN QUest of ITSELf 88-95 (I940).

${ }^{31} I d$. at Iro.

${ }^{32}$ See generally Fuller, Reason and Fiat in Case Law, 59 HARv. L. REv. 376 (I946); Fuller, Book Review, 9 U. CHr. L. REv. 759 (I942).

${ }^{33}$ Thus one does not find much sophistication in regard to megans-end relations 
of instruments. And problems of social ordering are divisible into two distinct stages: setting goals, and then devising means to achieve them. In Fuller's view, however, this misconceives the relations between means and goals in responsible social thought. ${ }^{34}$

Goals can orient and discipline analysis only when related to available means. It is seldom possible to define a social objective in abstraction from the means of realizing it. Instrumentalists tend to think merely that goals determine means. But means also help render goals determinate. We cannot, for example, understand "equal treatment" until we specify means of defining and administering particular forms of it.

Furthermore, goals and means interact. Goals tentatively point to means; means then indicate some reformulation of goals. This interactive process continues until the thinker adopts a means-goal hypothesis or abandons goals because acceptable means are unavailable. The structure of a goal may even be so intimately associated with specific means that means and goal cannot be distinguished.

Thus, specific means-goal hypotheses should be the object of evaluation. The desirability of a goal depends not only on any intrinsic worth it may have but also on the likely costs of the means used to achieve it (including goal sacrifices and economic costs). It depends also on what Fuller called "means surplus" collateral gains likely to be derived from projected means. ${ }^{35}$ It follows that problems of means are not merely technical; they too call for evaluative judgments.

The implications of Fuller's views for instrumentalists are profound. It is fundamentally wrong to conceive of laws as mere instruments in the service of goals external to those laws. Rather, laws are means-goal complexes. Legal institutions and processes also cannot be viewed simply as means. These phenomena partially determine life's possibilities and help shape whole patterns

in the writings of such classical figures as Gray, Holmes, and Pound. See, e.g., J.C. Gray, supra note 7; 3 R. Pound, supra note 9, at 3-373; Holmes, The Path of the Law, Io HaRv. L. REv. 457, 468-70 (1897). Of the classical figures, only Dewey was highly sophisticated about means and ends. See J. DewEy, The Theory of Valdation (I939). Dewey influenced Cook. See, e.g., Cook, Walter Wheeler Cook, in MY PHILOSOPHy of Law 49, 59-65 (I94I).

${ }^{34}$ His principal writings on this theme consist of: L. FuLLER, ANatOMx OF THE LAw 36-39 (r968); Fuller, American Legal Philosophy at Mid-Century, $6 \mathrm{~J}$. Legal Educ. 457, 473-8I (r954); Fuller, An Afterword: Science and the Judicial Process, 79 HARv. L. REv. I604, I626-28 (x966); Fuller, Memorandum, in ON the TEaching of Law IN the Liberal Arts Curriculums 37-43 (H. Berman ed. I956); Fuller, Means and Ends (I960) (unpublished manuscript on file with the author).

${ }^{35}$ See Fuller, Means and Ends 26 (I960) (unpublished manuscript on file with the author). 
of living. For example, a particular economic system (necessarily shaped and structured by law) not only serves to satisfy antecedent wants but also generates its own particular patterns of wants. It will not do to test such an arrangement by posing the instrumentalist's standard query: "Is its end acceptable, and does it serve that end well?" Instead, we must ask a more vague and complex question: "What can be said for the patterns of life that the arrangement creates?" 36

\section{Legal Validity and Law Creation}

Professor Fuller repudiated positivistic theories of legal validity in pragmatic instrumentalism (and in the philosophies of Kelsen, Austin, and others). According to such theories, "the law" is not a "brooding omnipresence in the sky." 37 Rather, "the law" is entirely manmade and made all at once. It is laid down by the legislature, or laid down or acted upon by judges (who may and do make the law, too). Except for case law, it takes the form of a relatively explicit and finished product: a statute, a regulation, an enacted custom, a written contract, etc. ${ }^{38}$ At least from the lawyer's point of view, all law ultimately reduces to predictions of what the official organs of final application (courts in our system) will do. ${ }^{39}$ Such predictions are based mainly on what these organs have done in the past.

Professor Fuller thought that this emphasis on what officials have done (and are therefore likely to do) neglects essentials. We should focus on what they were and are trying to do - on purposes and goals. To Fuller, every form of law, properly conceived, consists of both words and objectives, whether or not explicit. We cannot tell what "the law" means, and therefore cannot tell what it is, without determining what it is for. In this vital respect, "value and being are not two different things, but two aspects of an integral reality." 40 To adapt Fuller's own metaphor, if we

\footnotetext{
${ }^{36}$ Fuller felt strongly that our universities are not well organized to instruct about means and goals. Outside the law schools, students rarely confront problems of legal ordering in forms in which means and goals interact. Even if they study "policy sciences," this effort will be divorced from society's chief source of implementive means - the law. See Fuller, Memorandum, in ON the TeAching of LAW IN THE Liberal ARTS CURRICULUM 37-43 (H. Berman ed. I956).

${ }^{37}$ Southern Pac. Co. v. Jensen, 244 U.S. 205, 222 (I9r7) (Holmes, J., dissenting).

${ }^{38}$ Varying forms of these views are explicit or discernably implicit in J.C. Gray, supra note 7 , at 84-II2; 3 R. Pound, supra note 9, at 377-738; Holmes, supra note 33 , at $457-62$.

${ }^{39}$ See, e.g., J.C. Gray, supra note 7 , at 84-II2; K. Llewellyn, The Bramble BUSH I-I5 (I930); Holmes, supra note 33 , at $457-6$ I.

${ }^{40}$ L. FULLER, THE LAW IN QUEST OF ITSELF Ir (I940). Although Fuller thus conceived of a particular form of "the law" as an "is-ought" complex, he of course
} 
leave what the law is for out of our concept of what it is, we are left with something like a wheelbarrow, and an empty one at that. It can easily be pushed in almost any direction and, of course, has no power to go anywhere on its own. ${ }^{41}$ Yet law is not in fact like this.

Professor Fuller believed that positivism was not only unfaithful to our legal reality but unhealthy as well. In his view, the conceptions of citizens, legal actors, and theorists as to what can count as valid "law" may ultimately shape what the law becomes. ${ }^{42}$ Thus, if we embrace a formal and fiat-oriented theory of legal validity, we run the risk of "fall[ing] into a 'law is law' formalism." ${ }^{43}$ And to the extent that the risk materializes, this may influence moral ideas which thereafter reinforce the law. ${ }^{44}$

The law, then, is not like a mere datum of nature, such as a stone or a twig. And to the extent a form of law fails to fulfill its goals, it is less truly law - just as a steam engine that fails to fulfill its characteristic function is to that extent less truly a steam engine. ${ }^{45}$ Nor are there compensating gains from confining law merely to authoritative past actions (or predictions based thereon) without any reference to law's goals. It is sometimes argued, for example, that such gains would include more "fidelity to law" and more social peace. But positivism may actually disserve the cause of order. The order-minded tend to neglect the needs of good order, and this can lead ultimately to disorder, if not anarchy. ${ }^{46}$

Although nearly all instrumentalists saw vast scope for legislative and judicial creativity, and great need for legal reform, they evidently did not perceive the tension between these views and their positivistic theories. It is not even generally true that "the law" consists of an explicit and finished product - a "hard chunk of reality." 47 Gaps in the law arise. Authorities come into conflict. Original error and misjudgment occur. In the common law, it is frequently not even possible to draw a sharp dis-

allowed that this complex could itself be the object of criticism. See generally id.

${ }^{41}$ Id. at II4-I5.

42 "[I]n human affairs what men mistakenly accept as real tends, by the very act of their acceptance, to become real." Fuller, Positivism and Fidelity to LawA Reply to Professor Hart, 7 I HARv. L. Rev. 630, 63I (1958) ; cf. Dworkin, Judicial Discretion, $60 \mathrm{~J}$. PHILSOPHy 624, 638 (1963) (pointing out dangers of explaining judicial decisions as judges' exercises of discretion).

${ }^{43}$ Fuller, Positivism and Fidelity to Law-A Reply to Professor Hart, $7 \mathrm{I}$

HARV, L. REv. 630, 637 (1958).

${ }^{44}$ See L. Fuller, THe LAW IN Quest OF ITSELF 137 (r940).

${ }^{45} I d$. at II.

${ }^{46}$ See Fuller, American Legal Philosophy at Mid-Century, 6 J. Legad Educ. 457, 463-64 (I954).

${ }^{47}$ L. FULIER, THE LAW IN QUEST OF ITSELF 9 (I940). 
tinction between creation of new law and application of old law. Much in the law is nascent and inchoate. The ever-changing nature of society also dictates that law must change. ${ }^{48}$ In sum, numerous occasions to create new law (and to predict what it will be) inevitably arise in a modern legal order, and each time they do, positivism, according to Fuller, can offer little sustenance, for it is essentially a theory of preexisting law. Moreover, even preexisting law is not self-defining. Creative interpretation of all forms of law is required. Fuller's own writings on purposive interpretation of statutes rank with the best of the century. ${ }^{49}$

Law, then, can be neither created nor interpreted simply by researching authoritative historical events such as past promulgations and decisions. The law must be argued for. And in this, lawyers, judges, and others are not confined to arguments previously endorsed by officials..$^{50}$ They may and should formulate and entertain arguments simply on the basis of their intrinsic merits. Some positivists have warned that if the law's door is opened in this way, the wrong and the bad as well as the right and the good are sure to enter. Professor Fuller admitted that the concepts of reason which legal actors invoke to cope with novel cases, gaps, conflicts, errors, change, and issues of interpretation might themselves turn out to be wrong or bad. But he contended that when legal processes are open and subject to demands for public justification, few truly objectionable ideas will find their way into the law. He also argued that unreason and immorality are more likely when people conceive law formally as something simply laid down or acted upon by officials. ${ }^{51}$

Fuller stressed the creative facets of law, but he did not believe that the materials out of which law is to be constructed are utterly plastic or malleable for any purpose. Unlike the instrumentalists, he saw considerable scope for genuine discovery in lawmaking. He thought some conceptions of goodness and rightness are peculiarly applicable to the conduct of human affairs, The weight of reason is heavily on one side on many issues. This reality is not plastic. It is there for the lawmaker to discover and respect. ${ }^{52}$

Further, general facts of human nature, of institutions and

\footnotetext{
48 See generally L. FULLER, ANatomy of the LAw (Ig68).

${ }^{40}$ See, e.g., id. at I4-I8, 38-39, 57-60; L. FULLER, THE MORALITY OF LAW 8I91, 224-32 (rev. ed. I969); Fuller, Positivism and Fidelity to Law-A Reply to Professor Hart, 7I HARv. L. Rev. 630, 66I-69 (I958).

${ }^{30}$ See L. FuLLER, THe LAW IN QUEST OF ITSELF IIO-I7 (I940).

${ }^{51}$ See Fuller, Positivism and Fidelity to Law-A Reply to Professor Hart, 7I HARV. L. REv. 630, 636-38 (I958).

${ }^{52}$ See L. Fuller, The LAw IN QUest of ITSelf (1940); Fuller, Reason and Fiat in Case Law, 59 HaRv. L. Rev. 376 (I946).
} 
processes, and of the human condition rationally constrain what may by done through law. The relevance of any such facts and their corresponding constraints must also be discovered and respected. Even socially invented phenomena - institutions and processes - drastically delimit what is possible. ${ }^{53}$ Moreover, the very "creation" of some forms of law is to a considerable degree simply a matter of "finding facts." This is especially true with respect to customary practices that appropriately control the rights of participants.

\section{Law and Social Science}

Most pragmatic instrumentalists were enamored of scientific method. ${ }^{54}$ They respected facts, especially ones discovered by psychologists, sociologists, economists, and other social scientists. Some instrumentalists even appeared to think that the law's ends and means could be determined solely by resort to scientific method. ${ }^{55}$ Concededly, law ought to be made and implemented partly in light of ascertainable facts, and Professor Fuller entered his share of pleas for systematic studies, especially of legal institutions and processes. But he had a sharp eye for the uncritical use of scientific method in law and probably appreciated the limits of social science research more fully than any other major legal theorist of the day.

The problems of determining the ends and means of law by scientific methodology are manifold. Frequently science is of no avail because officials must make decisions before research can be done or its fruits realized. Furthermore, sociolegal subject matter may be significantly impervious to scientific method. Simplifying assumptions may be required, the intangible or nonnumerical broken into units and quantified, variables artifically held constant, and data "interpreted" in the face of uncertainties. $^{56}$ All these difficulties may plague even the apparently simplest inquiry into the social effects of a specific use of law.

Much social science is simply not well done. For example, some work focuses exclusively on "behavior" or other observables to the neglect of attitudes and beliefs. Yet to understand or explain legal activities, the social scientist must take into account

${ }^{53}$ See pp. 444-45 infra.

${ }^{54}$ See, e.g., Dewey, Logical Method and Law, to CorNerr L.Q. I7 (1924); Moore \& Sussman, supra note 13 ; Pound, The Scope and Purpose of Sociological Jurisprudence (pts. I-3), 24 HARv. L. Rev. 59I (I9II), 25 HARv. L. REV. I40, 489 (I9II-IgI2).

${ }^{55}$ See, e.g., Fuller, American Legal Realism, 82 U. PA. L. REv. 429, 453-6I (1934) (discussing Moore's views).

${ }^{56}$ See Fuller, An Afterword: Science and the Judicial Process, 79 HARv. L. Rev. I604 (Ig66). 
objectives of the participants. Although no one would try to explain the fall of a stone by saying that it is "moved by an impulse to rejoin its mother, Earth," ${ }^{57}$ legal activities are not like data of physical nature. They are fundamentally purposive in character.

The specialization of social scientists is bane as well as boon. On the one hand, sociolegal subject-matter may not fall within the "jurisdiction" of any particular social science, ${ }^{58}$ or it may be mutilated by diverse disciplinary approaches. ${ }^{59}$ On the other, the scientist appropriate for the task is more likely to be available. Attitudes and conceptions of what is right, for example, may be studied best not by the statistician but by the "ethnologist who can feel his way into a complex and unfamiliar moral environment" and who will not rely on scientific method alone. ${ }^{60}$

Overall, even if social science does have its day in court or in a legislative body, it may tell us little. Furthermore, even good social science is specially susceptible to political manipulation. ${ }^{61}$ Yet when science yields no reliable findings, it does not follow that we are left only with arbitrary preference. There are other forms of knowledge and understanding (a truth not obvious to some of the science-minded). ${ }^{62}$ And when science does yield reliable findings, these can play only a partial role in legal ordering. Decisionmakers must also bring ideas of right and good to bear through reasoning that mediates between these findings and projected decisions. ${ }^{63}$

Many social scientists seem content merely to seek predictability, but the ability to realize even this objective is inherently limited by a variety of factors. These include, according to Fuller, the creative character of much decisionmaking. Predicting an eclipse is one thing, predicting a decision like MacPherson $v$. Buick Motor $\mathrm{Co}^{64}$ another. A legal decision is not merely a result; it is a reasoned resolution as well. And unless we can predict that resolution, merely to "know" the outcome in advance may be of little value. A judge must often think innovatively. One who has worked through the judge's problem might within limits pre-

57 L. Fuller, ANatomy of the LAw iI5 (Ig68).

${ }^{58}$ See Fuller, Some Unexplored Social Dimensions of the Law, in THE PATH OF THE LAW FROM I967, at 57 (A. Sutherland ed. I968).

${ }^{59}$ See Fuller, Memorandum, in ON THE TEACHINg OF LAW IN THE LIBERAL Arts CurriculuM 37-43 (H. Berman ed. I956).

${ }^{60}$ See L. Fuller, THE LAW IN QUEST OF ITSELF 65 (I940).

${ }^{\circ 1}$ See Bloomfield, Equality of Educational Opportunity: Judicial Supervision of Public Education, 43 S. CAL. L. REv. 275, 285-89 (I970) (article inspired by Fuller) (suggesting the Coleman Report as an example).

${ }^{62}$ See L. Fuller, THe LAW IN QUeST OF ITSELF II8-i9 (1940); Fuller, Lon $L$. Fuller, in My PHIlosophy OF LAW III, II8-20 (I94I).

${ }^{63}$ See Fuller, Lon L. Fuller, in My PHmosophy OF LAW III, II8-20 (I94r).

${ }^{84} 2$ Iy N.Y. 382, III N.E. I050 (IgI6). 
dict the reasoned resolution, but few predictors will be in a position even to make this effort. ${ }^{65}$

Many instrumentalists thought of law as "experiments" and this, too, led them to the scientific study of law's effects. Fuller agreed that important facets of the law are always subject to modification in light of accumulated experience and are in this respect "experimental." However, as I will explain, he did not view basic "forms of social order" such as adjudication and contract in this light. Nor did he think of fundamental ideas of the right and the good in these terms.

\section{E. Forms of Legal Ordering}

Professor Fuller agreed with the social engineers of pragmatic instrumentalism that the resources of the law are vast and its technology sophisticated. Yet he rejected any corollary assumptions that the basic implementive "forms" of the law are themselves numerous and "infinitely pliable," and he held that the successful deployment of these forms requires careful choice. He repudiated the fringe of instrumentalists who appeared to believe that the choice of basic institution or process to implement (or even to create) law is relatively unimportant, provided that official personnel ultimately act to bring about the results we desire. ${ }^{00}$

For nearly two decades Fuller reflected upon basic "forms of social order" such as legislation, adjudication, mediation, markets, contracts, elections, and managerial direction. ${ }^{67}$ These forms are limited, and none is an "all purpose tool." Each has an inner integrity and hence its own distinctive utilities and limitations. In one of his most famous essays, widely circulated privately and now published in its entirety for the first time, Fuller explored the compulsions necessarily contained in adjudicative ordering. ${ }^{68}$ In his well known book The Morality of Law ${ }^{60}$ he dealt similarly with legislation.

${ }^{65}$ See Fuller, An Afterword: Science and the Judicial Process, 79 Harv. L. REv. I604, I6I8-28(I966).

${ }^{68}$ See Fuller, American Legal Philosophy at Mid-Century, 6 J. Legal Educ. $457,473-8$ r (r954).

${ }^{67}$ See id. See also L. Fulier, The Moratity of Law (rev. ed. I969); Fuller, Adjudication and the Rule of Law, 54 PRoc. AM. Soc'Y INT'L L. I (1960); Fuller, Collective Bargaining and the Arbitrator, 1963 Wis. L. Rev. 3 ; Fuller, Human Interaction and the Law, I4 AM. J. JURIS. I (I969) ; Fuller, Irrigation and Tyranny, I7 Stan. L. Rev. IO2I (I965); Fuller, Mediation-Its Forms and Functions, 44 S. Car. L. Rev. 305 ( $197 \mathrm{r}$ ); Fuller, The Forms and Limits of Adjudication, 92 Harv. L. Rev. 353 (I978) ; L. Fuller \& M. Eisenberg, Basic Contract Law 89Io7 (3d ed. I972); Fuller, Two Principles of Human Association, in Voluntary Associations 3 (J.R. Pennock \& J. Chapman eds. r969).

${ }^{68}$ Fuller, The Forms and Limits of Adjudication, 92 HARv. L. REv. 353 (x978).

${ }^{69}$ L. Fuller, The Moratity of LaW (rev. ed. I969). 
Fuller warned of the consequences of failing to heed the distinctive character of a form of social order. The price to be paid in the case of adjudication, for example, is a dual one. A judge who first tries to mediate (and thereby "learns" the facts of the case) and then seeks to determine the facts as an adjudicator may not only fail as factfinder but also forfeit some degree of impartiality, thereby tainting the process. ${ }^{70}$ Similarly, to assign adjudicators "polycentric" tasks (those calling for managerial control of diverse yet interdependent factors) is not only to put the achievement of those tasks at risk but to compromise the integrity of adjudication as well. ${ }^{71}$ In Fuller's view, those concerned with the law, no less than engineers, carpenters, and cooks, must master distinct "segments" of reality if they are to take advantage of regularities in the effort to further group life.

\section{F. Coercion}

Once created, law must be implemented. It is not self-executing. Nearly all classical adherents of pragmatic instrumentalism assumed or claimed that, in the main, coercion accounts both for public acceptance of lawmaking authority and for the implementive efficacy of law. ${ }^{72}$ Thus, they considered coercion to be a "distinguishing mark" of law. The authority of lawmakers depends on state power, and the efficacy of law's technology depends on official capacity to coerce.

Fuller thought this view false, not only in western liberal democracies but under totalitarian regimes as well. He refused to recognize coercion as even one "distinguishing mark" of law. ${ }^{73}$ In his view, people do accept the lawmaking authority not because they fear the state's monopoly of force but because they perceive that the authoritative setup is necessary, right, and good. ${ }^{74}$ In a particular instance, the people might perceive wrongly, but this would not affect Fuller's point.

This issue poses a subtle and complex question of social fact: in a significant proportion of societies, do people accept authority

${ }^{70}$ Fuller, Some Unexplored Social Dimensions of the Law, in The Patr of THE LAW FROM I967, at 57,60-6I (A. Sutherland ed. I968).

${ }^{71}$ Fuller, Adjudication and the Rule of Law, 54 Proc. AM. Soc'y INT'x L. I, 3-5 (Ig60).

72 Dewey and Holmes were especially emphatic. See, e.g., Dewey, Force and Coercion, 26 INT'ז J. ExHICS 359 (I9I6); Dewey, Force, Violence, and Law, 5 NEw RePUBLIC 295 (IgI6); Holmes, supra note 33, at 457-62. See also J.C. Gray, supra note 7, at I2, Ior, Ir6 (2d ed. I92I).

${ }^{73}$ L. Fuller, The Morality of LaW io8 (rev. ed. I969).

${ }^{74} \mathrm{Id}$. at 138 . See also Fuller, Jurisprudence, in I3 ENCycLopedia BritanNICA I49, I49-52 (I965); Fuller, Positivism and Fidelity to Law - A Reply to Professor Hart, 7I HaRv. L. Rev. 630, 638-43 (I958). 
mainly out of fear of state force? An affirmative answer seems unlikely. For one thing, the efficacy of state coercion presupposes that the public generally acquiesces in, or even affirmatively assists with, exercises of coercion. Normally, a "coercive order" cannot exist unless the number of those willing to go along vastly exceeds the number of those who are not. ${ }^{75}$ Except in the very short run (or perhaps in a very small society), it seems highly improbable that people will voluntarily go along unless they perceive that the coercive order is to a significant degree necessary, right, and good.

It is also possible, however, to formulate a species of "coercion theory" in less fundamental terms. According to this second (but closely related) version, the efficacy of law in everyday life and on particular occasions is attributable mainly to the use and threat of sanctions. Fuller observed, though, that citizens cannot orient their conduct to law simply on the basis of a series of sporadic and patternless exercises of coercion. ${ }^{76}$ In any event, the true conception is not force-backed law. It is law-backed force. ${ }^{77}$ But no approach in which force is central can explain behavior generally in accord with customary, contractual, judgemade, statutory, and other sources of obligation. In Fuller's view, this behavior is attributable mainly to the perceptions and assumptions of people that they ought so to behave and not to the consequences should they fail so to behave. ${ }^{78}$ The obligations of custom and contract, for example, are by and large self-imposed. ${ }^{79}$ The average citizen abides by the criminal law because he morally takes its prescriptions for granted. ${ }^{80}$ Common law duties are similar: there are no deep discrepancies between them and general notions of what is fitting and just. ${ }^{81}$

If Professor Fuller is right, one implication for state officials is plain. They must induce the populace to think that the existing setup is justified, even in totalitarian regimes. The best way for them to do this is to exercise their power responsibly and thus give the people good reason to think that the setup is justified. As Bentham once put it (in a remark Fuller was fond of quoting):

The way to be comfortable is to make others comfortable.

\footnotetext{
${ }^{75}$ See H.L.A. Hart, The Concept of Law I88-89 (I96I).

${ }^{76} \mathrm{~L}$. FULLER, The Morality of LaW IIo (rev. ed. I969).

${ }^{77}$ Fuller, American Legal Philosophy at Mid-Century, 6 J. Legar Educ. $457,46 \mathrm{I}-67$ (I954).

${ }^{78}$ Id. at $462-65$. See also L. Fuller, Tre LAw IN QUEST of ItSELF 90-9I (1940).

${ }^{79}$ L. Fuller, ANatony of the LAw 73-74 (ig68).

${ }^{80}$ See id. at 26-36.

${ }^{81} \mathrm{See} i d$. at ro3.
} 
The way to make others comfortable is to appear to love them.

The way to appear to love them - is to love them in reality. ${ }^{82}$

\section{G. The Role of Officials}

According to instrumentalists, officials in general and judges in particular - not private parties - occupy the key roles in legal processes. ${ }^{83}$ The extent to which law fulfills its goals is mainly a function of this human element and of technological know-how ("decision theories" for social engineers). According to the instrumentalists, ours is not a government of law but a government by men through law. Professor Fuller, in contrast, was not preoccupied with official personnel. He stressed the study of ideas of right and good in legal ordering and the study of forms of social order in addition to adjudication.

But the difference is more fundamental. Here, Fuller's background as a teacher and scholar of private contract deepened his insight. His was not a model in which officials on top control citizens on the bottom. If simplistic models must be invoked, then much law is "bottom to bottom" or "bottom to top," rather than "top to bottom." It consists of customary, contractual, and other forms of consensual law. It is self-imposed by private persons, not imposed from above by officials. For Fuller, the main province of law is not social control (let alone control by officials from above) but facilitation of human interaction. ${ }^{84}$ Our "bottom to top" law includes even the common law, much of which judges discover and cull from common ideas and morals. The primacy of private persons and nonlawyers in legal affairs extends to law administration as well as to lawmaking. Most law applied to citizens is applied by them, acting on their own, with no officials in sight (especially not judges).

\section{H. Criterion of Legal Success}

An ultimate criterion of legal success implicit in much instrumentalist thought is: In light of the law's effects, are its specific goals served with sufficient effectiveness? ${ }^{85}$ If so, the law as used is successful. So far as I know, Professor Fuller did

\footnotetext{
$82 \mathrm{~J}$. BentHaM, II Works $7 \mathrm{I}$ (J. Bowring ed. I843).

${ }^{83}$ See, e.g., J. Frank, CourTs on TrIAL (I949); J.C. GraY, supra note 7; Holmes, supra note 33 , at $457-58$.

${ }^{84}$ See Fuller, Law as an Instrument of Social Control and Law as a Facilitation of Human Interaction, r975 B.Y.U. L. REv. 89.

${ }^{85}$ This criterion is explicit in Dewey. See Dewey, John Dewey, in MY P\#ILOSOPHY OF LAW 73, 82-85 (I94I). 
not explicitly discuss this criterion. But it is central to instrumentalist thought, and what Fuller would have said about it is, I think, plain.

He saw complexities and difficulties that must generally plague "scientific" efforts to make efficacy judgments. ${ }^{86}$ He would have rejected any merely technological conception of legal success. Success must be judged more substantively, and therefore not merely in relation to predetermined goals but in relation to values that should figure in such goals (originally and in light of new facts about law's effects) ${ }^{87}$ He would have considered an efficacy criterion myopic, too. Law realizes values not merely as a result of its goal-serving effects but also as a result of its accordance with norms of right behavior applicable to past actions of individuals. That is, reasons for a decision may have justificatory force not because of the predicted effects of that decision but because of how the case came about. Our values are not merely future regarding but past regarding as well. ${ }^{88}$

Finally, Professor Fuller would have warned against tendencies toward result-oriented functionalism in the instrumentalist criterion. The realization of specific set goals may be bought too dearly, even when these goals are themselves good. For there are values at stake simply in the course of the law's workings: "rule of law" values, "division of legal labor" values, and "process" values. Law is a complex enterprise and it implicates values in all these ways, as well as in its end products. Indeed, in law, ultimate results are often less important than how they are arrived at.

\section{III}

It is of course not true that Professor Fuller found nothing of value in pragmatic instrumentalism. ${ }^{80}$ Although I have emphasized oppositions between his views and that philosophy, it should be evident that he accepted some of its root tenets and merely sought to render them more sophisticated. He applauded the revolt against formalism in jurisprudence, the attack on concep-

${ }^{88}$ See pp. $442-44$ supra.

${ }^{87}$ See, e.g., L. Fuller, The LAW IN QUEST OF ITSeLF (I940).

${ }^{88}$ Id. See also Fuller, Reason and Fiat in Case Law, 59 HaRv. L. Rev. 376 (I946). I have dealt with this distinction at length in Summers, Two Types of Substantive Reasons: The Core of a Theory of Common Law Justification, 63 CORNELI L. REV. 707 (r978).

${ }^{89}$ Among the leading instrumentalists, Professor Fuller probably admired Dewey most. Dewey himself rejected the positivist planks in the dominant philosophy and also held sophisticated views on the relations between ends and means. See, e.g., J. Dewey, The Theory of Valdation (I939); Dewey, Austin's Theory of Sovereignty, 9 PoLITICaL Scr. Q. 3 I (I894). 
tualism in the law, and the broadening of concerns that accompanied these developments..$^{90}$ Like the instrumentalists, Fuller thought of legal ordering as a goal-directed enterprise concerned with problems of group life. Law must be studied in the context from which it arises and with which it deals. The pervasive change that characterizes life has many implications for "existing" law. Fuller even embraced some of the "realism" of the instrumentalist philosophy. In particular, he praised efforts to show that what judges and lawyers consider relevant actually includes more than the mere language of written law and precedent. He agreed (within limits) that we must take into account not only what judges say but what they do as well.

There is far more to Professor Fuller's writings than my chosen theme can bring to light. I have sought to put his thought in perspective (and then only in relation to the dominant philosophy of his day). I suspect that its richness is, for varied and complex reasons, likely to be more fully appreciated in the future than it was during his lifetime. But before his passing, there were already signs in print. ${ }^{21}$ These he welcomed, insofar as he thought they approximated the truth. For truth in jurisprudence was his ideal, and about this no one cared more passionately.

\footnotetext{
${ }^{90}$ See Fuller, American Legal Realism, 82 U. Pa. L. Rev. 429 (I934); Fuller, Williston on Contracts: Revised Edition, I8 N.C.L. REv. I (I939).

${ }^{91}$ Compare Dworkin, Philosophy, Morality, and Law-Observations Prompted by Professor Fuller's Novel Claim, Ix3 U. PA. L. REv. 668 (1965), and Dworkin, The Elusive Morality of Law, to VIIL. L. REv. 63I (I965), with R. DwORKIN, TARING Rigmts Serrousiy (r977), a book in which the author, among other things, admirably develops several themes adumbrated in L. FULLER, THE LAW IN QUest of ITSELF (r940) and Fuller, Positivism and Fidelity to Law-A Reply to Professor Hart, 7 I HARv. L. Rev. 630 (I958). Compare Summers, Professor Fuller on Morality and Law, I8 J. LEGAL EDUC. I (rg65), reprinted in More Essays IN Legal Phirosophy IOI-30 (R. Summers ed. I97I), with Summers, The Present State of Legal Theory in the United States, 6 RECHTSTHEORIE 65, 78-79 (1975).
} 